\title{
THE IMPLEMENTATION OF SCIENTIFIC APPROACH IN TEACHING ENGLISH READING COMPREHENSION AT 11 GRADE STUDENTS OF SMA MATHLA'UL ANWAR
}

\author{
Rian Melyadi ${ }^{1}$, Odo Fadloeli \\ ${ }^{1}$ IKIP Siliwangi \\ ${ }^{2}$ IKIP Siliwangi \\ ${ }^{1}$ rianmelyadi18@gmail.com, ${ }^{2}$ Odofadloeli@upi.ac.id
}

\begin{abstract}
The aim of the research is to improve students' reading comprehension through a scientific approach. The research was conducted at SMA Mathla'ul Anwar in the first semester. The researcher used the method of the research is qualitative research, a classroom action research. The research used three cycles. Any cycle exists in four steps. There are planning, action, observation, and reflection. The subjects of the research were 32 students at XI IPA 1 of SMA Mathla'ul Anwar. The researcher collected the data using observation, interview, test, and discussion to collect data that need at the time of the study. It determined the extent of the increase students' reading comprehension before and after the following scientific approach. most of them have low motivation in the learning activity. Students whose English are good enough have good motivation in the learning activity. Most of the students have low willingness to learn especially when they entered the noon hour lesson.

The analysis of the research data showed that there was an increase in the average and percentage students' score, from the score in cycle I am 65 or $37.5 \%$, cycle II is 71 or $59 \%$, cycle III is 80 or $100 \%$. It can be said that scientific approach improved students' reading comprehension at XI IPA 1 of SMA Mathla'ul Anwar in Academic 2018/2019.
\end{abstract}

Keywords: Students, Improving reading comprehension, Scientific approach

\section{INTRODUCTION}

Language has four skills which are speaking, reading, listening, and writing. Reading is an important language skill because without it people cannot get the variety of information which is obtained through reading newspapers, textbooks, and magazines. (Grellet, 1981) states that reading is an active skill, and it always involves predicting, guessing, checking, and asking yourself. Furthermore, Nunan in (Nuringtyas, 2003) states the reading as consisting of four elements; it is text, reader, fluency, and strategy. Especially reading comprehension is not a passive activity. Actually, at a higher level, reading is not just understanding written symbols, but also understanding, accepting, rejecting, comparing and believing in the opinions in the reading. Reading comprehension is an important component in a reading activity because, in essence, reading can improve reading skills, self-owned reading, or reading for the objective of reading. (Andreson, 2003) states reading comprehension can be significantly enhanced if background knowledge can be activated by setting goals, asking questions, making predictions, teaching text structure, and other things.

According to (P. Pearson \& D. Jhonson, 1979), reading comprehension involves language, motivation, perception, concept development, and overall experience. In reading activities, response to symbolic stimuli is needed, namely the words that are in reading. Therefore, Richard in (Parmawati \& Yugafiati, 2017) state the main objective for reading is somewhile 
ignored when students are asked to read difficult text; raising student's consciousness of main ideas in a text and exploring the organization of a text is essential for good comprehension. That understanding is done by interpreting the meanings that are in words and sentences so that the reader understands or knows the message conveyed the author through the reading. Existing language skills, namely listening, speaking, reading, writing and literary skills are among the English learning that use a scientific approach to the learning process.

The scientific approach was born by adopting scientific learning. In this sense, the scientific approach has the characteristics of a marker as a learning process that can be matched with a process of scientific discovery. Scientific learning is also born because of the 2013 curriculum. The 2013 curriculum or the so-called K-13 refers to observing the essence of the scientific approach. The scientific approach is believed to be a golden sign of developing and developing student attitudes, skills and knowledge.

The scientific approach refers to investigative techniques for a circumstance, acquiring new knowledge, or correcting and assimilating prior knowledge. To be called scientific, the method search (method of inquiry) must be based on evidence from objects obtained from observations, empirical, and measured by the principles of particular observations.

In the understanding of the scientific approach, there are several steps, according to (Musfiqon $\&$ Nurdyansah, 2015), the learning process consists of five main learning experience activities namely:

\section{Observing}

Observing methods prioritize the meaningfulness of the learning process. This method has certain advantages, such as presenting objects in a real way, students are happy and interested, and easy to implement.

2. Asking

Effective teachers are able to inspire students to improve and develop the realm of attitudes, skills, and knowledge. When the teacher asks, at that time the teacher guides or guides the students to learn well.

3. Collecting Information / Experiments

The "Collecting information" activity is a follow-up to asking. This activity is carried out by exploring and gathering information from various sources in various ways.

4. Associating / Processing information

is processing information that has been collected both limited to the results of collecting or experimental activities or the results of observing activities and collecting information.

5. Communicating.

This activity is carried out through writing or telling what is found in activities seeking information, associating, and finding patterns. These results are delivered in class and assessed by the teacher as a result of learning of students or groups of students.

In practice, the English teaching and learning process of students is faced with various difficulties in Reading's comprehension, from those difficulties that have an impact on understanding the text which is difficult to achieve the true meaning of reading. Based on the theory above, the researcher decides to utilize the Scientific approach in teaching reading comprehension and want to measure the success of the Scientific approach in the reading comprehension class. The researcher assumes that the Scientific approach can improve the students' reading comprehension at SMA Mathla'ul Anwar. 


\section{METHOD}

The design of this research uses Classroom Action Research, (Khasinah, 2015) state Action Research is a process in which educators examine their own practice systematically and carefully using the techniques of research. Besides, (Burns, 2010) states the main aims of AR is to identify a 'problematic' situation or issue that the participants - who may include teachers, students, managers, administrators, or even parents. The point is that, as teachers, we often see gaps between what is actually happening in our teaching situation and what we would ideally like to see happening. It process which consists of four essential moments: planning, acting, observing and reflection. This is a type of classroom action research conducted collaboratively between the principal, teacher, and researcher with the effort to improve students' reading comprehension using a scientific approach.

The subject of the research is all of the student's XI IPA 1 of SMA Mathla'ul Anwar. The researcher chose eleventh-grade students. It consists of 32 students. There are 22 girls and 10 boys. Here, the researcher as an English teacher in the class will teach the material of reading comprehension.

\section{RESULTS AND DISCUSSION}

\section{Results}

\section{The Technique of Collecting Data}

Data is an absolute requirement of research. It is a means of proving a hypothesis. Data are used to solve or answer the problems of the research. In order to get the appropriate data, it must be collected by using the appropriate method. In the methods used by is a researcher is an observation in the process of teaching and learning, questionnaire and test for students.

\section{Classroom Observation}

Observation is carried out to record data that includes the process and result of the implementation of activities to gather evidence of the actions to be evaluated and used as the basis in reflection. The researcher conducted this technique in each action.

\section{Interview}

The researcher does an interview with the students after cycle, also did an interview with the headmaster. The purpose of the interview is to know more about the quality of the student's English at school.

\section{Students' Test}

Collecting data used in this research is to give a closed test to the student. It was conducted at each end of the lesson in class. In this technique to determine each cycle comprehension, as well as a comparison of students' reading comprehension of each cycle.

\section{Data Analysis}

The researcher explained the technique and analysis of the criteria that are used to analyze data as follow:

1. Data Reduction: the researcher conducted the selection of relevant data 
2. Data Description: the researcher presented data, both quantitative data and qualitative data. These data are information that can be a conclusion for the researcher. Data description is presented descriptively. It is in a verbal statement, symbol, table, chart, and pictures

3. Data Verification: the researcher interpreted data based on data description result

\section{Validity of Data}

According to Lather in (Arikunto, 2006), there are four strategies to make the instrument are valid. The strategies are:

Table 1. Process of validity data

\begin{tabular}{l|l}
\hline Face Validity & $\begin{array}{l}\text { the researcher checks, scores, and decides the validity of the instrument in } \\
\text { the collaboration process }\end{array}$ \\
\hline Triangulation & $\begin{array}{l}\text { the instrument is taken by using some data sources to improve the quality } \\
\text { of evaluation }\end{array}$ \\
\hline Critical reflection & the cycle is planned to improve the quality of understanding \\
\hline Catalytic validity & $\begin{array}{l}\text { the instrument is gotten from the researcher's knowledge as the effort to } \\
\text { get improvement }\end{array}$
\end{tabular}

In this research, the researcher used face validity, it is observed the students learning and then make a score of them to collaboration with another instrument, it is triangulation that instrument taken by using some data and then critical reflection, it is about planning for improving students' reading comprehension by cycle.

\section{Criteria of the Successful Research}

Classroom Action Research (CAR) is able to be called successful if it can exceed the criteria which have been determined. In this research will succeed when there is $100 \%$ of students could pass the assessment score $\geq 70$ based on the minimal mastery level criteria (KriteriaKetuntasan Minimal / KKM) which is adapted from the school agreement (SMA Mathla'ul Anwar).

\section{Steps of the Research}

The subject in this research is all students of XI IPA 1 of SMA MATHLA'UL ANWAR. The implementation of actions in the Classroom Action Research. It was done includes four steps: 1) Planning action, 2) Implementation of the Action, 3) Observation and, 4) Reflection. We can see the result of the research from cycle I until cycle III from the research below:

Table 2. Progress of students in Cycle I

\begin{tabular}{cc|l}
\hline No & Action & \multicolumn{1}{c}{ Description } \\
\hline 1 & Planning & $\begin{array}{l}\text { In the first cycle, The researcher prepared the material a report text } \\
\text { genre from the textbook, The researcher formulated the design of } \\
\text { action: to determine lesson plan using scientific approach and } \\
\text { evaluation instrument, to determine research instrument }\end{array}$ \\
\hline 2 & Acting & $\begin{array}{l}\text { The researcher explained to students about the report text. Then } \\
\text { students were asked to observe what has been explained, after that }\end{array}$
\end{tabular}




\begin{tabular}{l|l}
\hline \multirow{3}{*}{ Observing } & $\begin{array}{l}\text { student were asked to ask what is contained in the report text, after that, } \\
\text { students were asked to collect and process information from other } \\
\text { sources, then students were asked to read what they have gotten from } \\
\text { other sources about report text. } \\
\text { The aspect observed are the activities of students during the teaching- } \\
\text { learning process either individually or in pair, the students' ability to } \\
\text { show their reading comprehension. }\end{array}$ \\
\hline $4 \quad$ Reflecting & $\begin{array}{l}\text { Based on data gotten from the observation to the studying process in } \\
\text { this cycle, there are some points gotten, those are: the students' } \\
\text { enthusiastic is good enough but they are still low in reading } \\
\text { comprehension because they often practice read a text in the school. } \\
\text { The students always make some mistake in pronounce. So the } \\
\text { researcher will continue to apply next cycle with different situation that } \\
\text { more fun and enjoy learning. }\end{array}$
\end{tabular}

Table 3. Progress of Students in Cycle II

\begin{tabular}{|c|c|c|}
\hline No & Action & Description \\
\hline 1 & Planning & $\begin{array}{l}\text { The researcher makes the planning of acting based on reflecting in the } \\
\text { first cycle. The researcher arranges the lesson plan that will be done by } \\
\text { the scientific approach in cycle II. The researcher chose the material } \\
\text { about the narrative text that contents the simple past tense. }\end{array}$ \\
\hline 2 & Acting & $\begin{array}{l}\text { After the researcher explained the narrative text, students were asked } \\
\text { to read the narrative text and translate it and ask what they did not } \\
\text { understand. Then they were asked to make sentences using simple past } \\
\text { forms orally. The researcher asked them to make narrative texts about } \\
\text { the topic. After that, the researcher went around checking the work of } \\
\text { students. After students complete the narrative text, the researcher } \\
\text { checks the text so students use right English. }\end{array}$ \\
\hline 3 & Observing & $\begin{array}{l}\text { The data collection of classroom action research is observed from the } \\
\text { researcher and students' activity during the learning process. The result } \\
\text { of the test is better than before. The average is } 71 \text {. There is progress } \\
\text { and some of the students are able to presentation well and confidently. } \\
\text { Although some of the students do it well but it still there are some } \\
\text { students hesitate to do a presentation and still do the same mistake in } \\
\text { pronunciation when they read. In addition, they do not understand what } \\
\text { the text means and have a limit vocabulary building. }\end{array}$ \\
\hline 4 & Reflecting & $\begin{array}{l}\text { There is progress in cycle II. Some students are active and look very } \\
\text { excited. They are more enthusiastic about reading the text in front of } \\
\text { the class. In this cycle, some students have got the concept and they } \\
\text { understand what the researcher explained. They can search for } \\
\text { meaning in their smartphone dictionary. But there are some students } \\
\text { who are still embarrassed to convey what they read and often several } \\
\text { times they are wrong in pronunciation. }\end{array}$ \\
\hline
\end{tabular}

Table 4. Progress of Students in Cycle III

\begin{tabular}{lll}
\hline No & Action & \multicolumn{1}{c}{ Description } \\
\hline 1 & Planning & $\begin{array}{l}\text { The researcher makes some activity planning based on reflecting in } \\
\text { cycle II. The researcher arranges the lesson plan that will be done by } \\
\end{array}$ \\
& using small group, discussion in cycle III. The researcher chooses the
\end{tabular}




\begin{tabular}{|c|c|c|}
\hline & & $\begin{array}{l}\text { material about analytical exposition. The researcher divided the } \\
\text { students into eight groups. Each group contained four or five students. } \\
\text { The researcher prepares an evaluation sheet as the material of reading } \\
\text { comprehension through a scientific approach for the students and the } \\
\text { researchers' performance during the teaching process. The strength } \\
\text { that the researcher can see: The students are more confident when } \\
\text { reading a text even they do some mistake, it does not bother them. The } \\
\text { students feel excited and interested in the learning process using } \\
\text { scientific approach They feel free to express their ideas with their } \\
\text { friends for making a good text. }\end{array}$ \\
\hline & Acting & $\begin{array}{l}\text { The researcher gave one text of analytical exposition to each group. } \\
\text { Every group was asked to read the text, find the meaning of some } \\
\text { difficult words that they didn't know before through a dictionary and } \\
\text { then discussed its translation. After that, they were asked to read aloud } \\
\text { the text and its translation by group one by one and answered the } \\
\text { questions based on the text. }\end{array}$ \\
\hline 3 & Observing & $\begin{array}{l}\text { The research observed that the students were more active if they } \\
\text { worked in a group. This technique also helped the students who have } \\
\text { a problem with their pronunciation and grammar. Because in their } \\
\text { group, they would discuss the difficulties they found in the text. }\end{array}$ \\
\hline & Reflecting & $\begin{array}{l}\text { There was an enhancement in their reading ability. The responses } \\
\text { showed that had motivation in learning reading. Their enthusiasm was } \\
\text { high when that researcher divided them into groups. The score of } \\
\text { students in cycle III follows: the pass students' are } 32 \text { and the fail } \\
\text { students are } 0 \text {. The average was } 80\end{array}$ \\
\hline
\end{tabular}

\section{Discussion}

The average cycle I am 65 and the percentage are $36 \%$, the average of cycle II are 71 with percentage are $58 \%$, and decided to end the research percentage is $100 \%$. It means the researcher can get a learning target. According to the observation in cycle I, through Scientific Approach in cycle I the research brought into relief that not all students score reached the minimum mastery criteria (KKM) 70 only 12 students or $36 \%$. There was little improvement in students' reading comprehension. There were most of the students didn't understand what the text means. The reflection for next was clearly in explaining and ordering to the students. In action 2 of the cycle, this action results better than cycle I 19 students or $58 \%$ of students passed minimum criteria. According to the observation, there was an improvement in the students' reading comprehension through Scientific Approach. But there were still some students don't understand a meaning difficult word of the text. In the last action of the cycle, as the result in cycle three was improving all of the students have passed the minimum mastery of 32 students or $100 \%$. According to the observation, there was an improvement. Most of the students can read a text fluently and understand what the content of the text means.

Besides most of them have a good pronunciation. Scientific approach can improve the students reading comprehension. Use native language to communicate in the learning process. From the three cycles which were done by the researcher, the result of it can be described as follow:

Cycle I: There are 12 pass students of the 32 students There are 21 fail students of the 32 students And the average of the cycle $\mathrm{I}$ is 65

Cycle II: There are 19 pass students of the 32 students 
There are 13 fail students of the 32 students and the average of cycle II is 71

Cycle III: There are 32 pass students of the 32 students

There are 0 fail students of the 32 students

and the average cycle III is 80

To make clear the result above, It can be seen by this following:

Table 5. Result of each Cycle

\begin{tabular}{ccccc}
\hline Cycle & Pass & Fail & Average & Percentage \\
\hline Cycle 1 & 12 & 21 & 65 & $37.5 \%$ \\
\hline Cycle 2 & 19 & 13 & 71 & $59 \%$ \\
\hline Cycle 3 & 32 & 0 & 80 & $100 \%$
\end{tabular}

The result shows that there is an enhancement in the test result. It can be shown through the average. They are 65 in cycle I, 71 in cycle II, and 77 in cycle III. To make it clear the enhancement of the test result above, it can be seen by this following graphic:

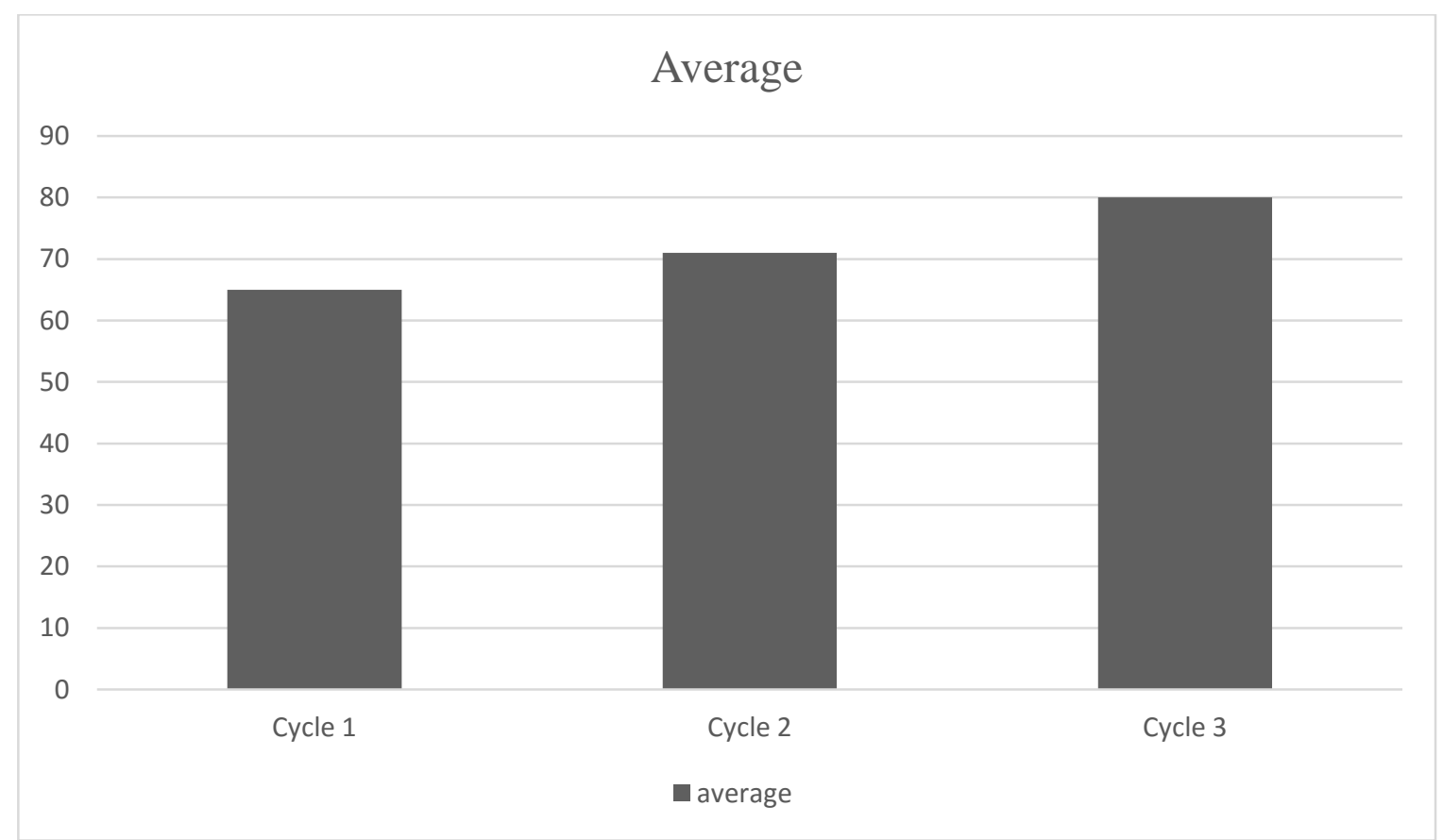

Figure 1. Result of Class Action Research

Based on the observation result of the students' activity in the classroom and the evaluation of the students' reading comprehension score, It can see that the improvement of the students reading competence and the students activities have been improved. The result of the reflection in the cycle showed that here were some improvements in the students' reading comprehension from cycle one until cycle three.

After doing the research, the researcher finds that some of the students of the XI IPA 1 of SMA MATHLA'UL ANWAR have good ability in reading. Because most of them come from families whose economy is middle and upper class. Students already have basically English course in which they follow. Unfortunately, most of them have low motivation in the learning activity. Students whose English are good enough have good motivation in the learning activity. Most of the students have low willingness to learn especially when they entered the noon hour 
lesson. The low of students 'willingness to learn influences the teacher's spirit in teaching. In addition, it is the teachers who are sometimes fewer enthusiasm influences the learning activity. Besides the teacher hasn't found the right method to be applied to the students who have low motivation in learning.

\section{CONCLUSION}

Based on the research result of THE IMPLEMENTATION OF SCIENTIFIC APPROACH IN TEACHING ENGLISH READING AT 11 GRADE STUDENTS OF SMA MATHLA'UL ANWAR, the researcher gives conclusion that ability of students' reading comprehension through Scientific Approach improve significantly with average in cycle I average score is 65 or $36 \%$, cycle II average score is 71 or $58 \%$, cycle III average score is 80 or $100 \%$. This is revealed when the students could answer the question and it can read the text fluently. Scientific Approach is proved to be effective in improving students' reading comprehension. Students can easily understand reading a text. Students should be active to practice reading from the kind of material given by the teacher and some information from mass media. In order to make students can get a better result in learning English.

\section{ACKNOWLEDGMENTS}

Alhamdulillahirabbil'alamin, all praise to Allah SWT who has given the writer patience and strenght so the writer could finish this article.

\section{REFERENCES}

Andreson, N. (2003). Practical English Language Teaching. (Da. Nunan, Ed.) (Asia). Singapore: Mc Graw Hill.

Arikunto, S. (2006). Prosedur Penelitian: Suatu Pendekatan Praktik. Jakarta: Pt Rineka Cipta. Burns, A. (2010). Doing Action Research In English Language Teaching. Madison Ave: Routledge.

Grellet, F. (1981). Developing Reading Skills. English: Cambridge University Press.

Khasinah, S. (2015). Classroom Action Research. Jurnal Pionir, 1, 107-114.

Musfiqon, \& Nurdyansah. (2015). Pendekatan Pembelajaran Saintifik (1st Ed.). Sidoarjo: Nizamia Learning Center.

Nuringtyas, D. P. L. (2003). The Implementation Of Extensive Reading Activity To Teach Reading A Descriptive Text To The Seventh Graders Of Smp Muhammadiyah 4 Surabaya, $1-8$.

P. Pearson, D., \& D. Jhonson, D. (1979). Teaching English Comprehension. San Diego: Harcourt College Publishers.

Parmawati, A., \& Yugafiati, R. (2017). Using Authentic Material To Improve Students'reading Interest (A Classroom Action Research In The Second Semester Students Of Stkip Siliwangi Bandung). Eltin Journal, Journal Of English Language Teaching In Indonesia, $5(1), 1-8$. 